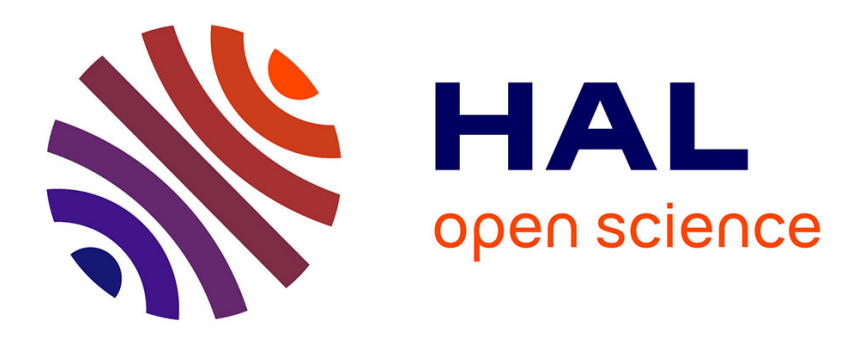

\title{
THE 2001 CENSUS - TO TICK OR NOT TO TICK THE EXISTENCE OF AN IRISH ETHNIC IDENTITY IN ENGLAND? \\ Grainne O'Keeffe-Vigneron
}

\section{- To cite this version:}

Grainne O'Keeffe-Vigneron. THE 2001 CENSUS - TO TICK OR NOT TO TICK THE EXISTENCE OF AN IRISH ETHNIC IDENTITY IN ENGLAND?. Etudes Irlandaises, 2006, 31.1, pp.169-181. hal-00607538

\section{HAL Id: hal-00607538 \\ https://hal.science/hal-00607538}

Submitted on 9 Jul 2011

HAL is a multi-disciplinary open access archive for the deposit and dissemination of scientific research documents, whether they are published or not. The documents may come from teaching and research institutions in France or abroad, or from public or private research centers.
L'archive ouverte pluridisciplinaire HAL, est destinée au dépôt et à la diffusion de documents scientifiques de niveau recherche, publiés ou non, émanant des établissements d'enseignement et de recherche français ou étrangers, des laboratoires publics ou privés. 
For reference purposes : Grainne O'Keeffe, 'The 2001 Census - To Tick or Not to Tick, The Existence of an Irish Ethnic Identity in Britain', Etudes Irlandaises, Printemps 2006, No.31.1, pp.169-181.

\title{
THE 2001 CENSUS - TO TICK OR NOT TO TICK THE EXISTENCE OF AN IRISH ETHNIC IDENTITY IN ENGLAND?
}

\author{
Gráinne O'KEEFFE \\ (Université du Havre)
}

\section{Résumé/Abstract}

Le recensement britannique de 2001 inclut pour la première fois la catégorie " Irlandais » sous la rubrique "groupe ethnique». Le nombre de personnes qui opta pour cette catégorie fut moins important que prévu, surtout pour la deuxième génération irlandaise. Ceci remet en cause l'existence d'une véritable identité « ethnique » irlandaise et l'utilité de garder cette catégorie dans le prochain recensement. Cet article propose d'examiner si une identité ethnique irlandaise est revendiquée par la communauté irlandaise en Angleterre et comment on peut expliquer le faible taux de réponse à la question sur l'ethnicité dans le recensement national.

Mots-clés : deuxième génération, ethnicité, identité, invisibilité, recensement.

An "Irish" category under the "Ethnic Group" question was included for the first time in the 2001 Census in Britain. The number of people who chose to tick this category was much less than expected especially for the second-generation Irish. This calls into question the veritable existence of an Irish "ethnic" identity and the usefulness of keeping this category in the next census. This article proposes to ascertain whether the Irish community in England recognises an Irish ethnic identity and how the low response rate to the ethnicity question in the national census can be explained.

Key words: second-generation, ethnicity, identity, invisibility, census. 
The Irish were included for the first time under the "Ethnic Group" category in the 2001 Census. The number of people in England who chose to tick this box was much lower than originally anticipated. The existence of an Irish "ethnic" identity has thus been called into question. This article will discuss whether or not the Irish community in England recognises an "Irish" ethnicity and the reasons why a greater number did not choose to tick this box. Particular attention will be paid to the second-generation Irish who had, for the first time in a national census, the chance to express their Irish identity and who did not do so in the anticipated numbers.

Firstly, the construction of the Irish migrant generation as an "invisible" minority in the period following the Second World War will be analysed. This meant that an Irish dimension was often missing in regard to central and local government policymaking and in official discourse concerning England's ethnic minorities. The Irish migrant generation and their children were subject to a "forced inclusion" into mainstream white society where their difference and identity were often ignored. This invisibility did not necessarily mean that the Irish did not suffer from many of the same problems as the "visible" minorities such as discrimination or unequal access to benefits or that an Irish identity ceased to exist on English soil. This did signify however that Irish immigrants and their children lacked recognition. The Irish-born were first "invisible" as an immigrant population and subsequently, with their children, as an ethnic group. An ethnic identity came to be constructed in official discourse as something only "visibly" different groups - i.e. non-white groups - possessed.

The second-generation Irish will then be examined in order to ascertain if they feel a particular affinity for their Irish background and heritage and if they see this part of their identity as a positive attribute and something to embrace. The second-generation Irish, being white and having English accents, have the option to choose which part of their identity they wish to make public. We will examine how they negotiate the various dimensions of their identity in English society.

The final part of this article will analyse the census question on ethnicity. Some explanations will be advanced as to why the second-generation did not take the opportunity given by the census to express the existence of their Irish heritage and background in the numbers that were hoped for by the Irish lobby. This lobby, made up mainly of the Irish voluntary sector, had worked for more than ten years for the inclusion of this category in the national census. It will be concluded that a number of different factors are at play, not least the years of "invisibility" of the Irish community as a separate and distinct ethnic group in official discourse in England.

\section{The creation of the myth of a British white homogenous society}

In the period following the Second World War, the British government began to discuss the possibility of introducing immigration controls to control the 
large influx of immigrants into Great Britain, especially those from the Commonwealth. The case of Irish immigrants became problematic as the British government was reluctant to introduce controls between the Republic of Ireland and Great Britain and in 1955, a Working Party gave the following arguments to support the continuing freedom of movement of Irish immigrants between both countries:

Citizens of the Irish Republic present a very difficult problem in that their exclusion from the scope of a Bill applying restrictions to the entry of British subjects would be open to obvious criticism on political grounds. However, the Irish not only provide much-needed labour but have always done so, and any restoration of the immigration control on traffic between GB and Ireland would be tiresome to the hundreds of thousands of passengers who travel each way during the year and would mean a considerable increase of the Immigration Service and the carrying of passports or other identity documents by citizens of Northern Ireland who would much resent it. The Working Party have previously pointed out that the only way out of this dilemma would appear to be to argue boldly along the lines that the population of the whole British Isles is for historical and geographical reasons essentially one and, except during the special circumstances of the war when Eire was a neutral state though still within the Commonwealth, has always been treated as such and that there is every reason on grounds of common sense and expediency for no departing from that principle in the present connection. ${ }^{1}$

This citation gives many reasons for exclusion of the Irish from possible immigration controls but what is particularly noteworthy however is the argument that, "the Irish and the British are, unlike Commonwealth citizens, essentially the same". The Working Party continued by declaring that, "the Irish are not, whether they like it or not, a different race from the ordinary inhabitants of Great Britain". The Irish were constructed as the "same" as "not different" from ordinary British citizens and their shared skin colour played a significant role in this construction.

Consequently, when the British government finally introduced legislation to control immigration, the 1962 Commonwealth Immigration Bill, the Irish were excluded ${ }^{3}$. They were not to be treated "any differently than British citizens" and could travel to and from Britain without hindrance. According to Mary Hickman, the exclusion of the Irish from controls on entry at this time directly contributed to

\footnotetext{
${ }^{1}$ Report of the Committee on the Social and Economic Problems arising from the Growing Influx into the United Kingdom of Coloured Workers from Other Commonwealth Countries, Appendix 2, draft statement on colonial immigrants, para. 3, 3 août 1955, CAB 129/77 p. 297, cité dans Zig Layton-Henry, The Politics of Immigration - Immigration, 'Race' and 'Race' Relations in Post-War Britain, Oxford, Blackwell Publishers, 1992, p. 33.

2 Idem.

${ }^{3}$ Mary Hickman, "Reconstructing Deconstructing 'Race': British Political Discourses about the Irish in Britain”, Ethnic and Racial Studies, vol. 21, no.2, 1998, p. 299.
} 
their subsequent forced inclusion in British society ${ }^{4}$. The non-inclusion of the Irish in immigration controls meant they were not officially recognised as immigrants unlike those from the Commonwealth. These immigrants and their children subsequently became England's "ethnic minorities". The Irish, already not officially considered an immigrant population group, were not, as a consequence, constructed as an "ethnic minority" group in England. Therefore an Irish dimension was subsequently ignored in debates surrounding harmonious race relations.

On the one hand, Irish immigrants were officially told that they were not different from the dominant white, British population for historical and geographical reasons but, on the other hand, they experienced discrimination and anti-Irish prejudice in their day-to-day lives. They were often forced to be discreet about their identity, not speaking to avoid revealing an Irish accent or instead anglicising it, not mentioning any clearly Irish name or by not making reference to Ireland or Irish culture ${ }^{5}$.

For Irish emigrants, who came over in the 1950s or the 1960s, playing down their Irishness became a feature of their lives in England. Many of them saw signs on doors, when they were looking for accommodation or employment, saying, "No blacks. No dogs. No Irish", For many expressing their Irishness was limited to the home or to times when they were with other Irish people. The Commission for Racial Equality (CRE) report on the discrimination of the Irish in Britain, the first of its kind concerning the problems the Irish community faced in Britain, cited numerous examples of Irish discrimination and stereotyping in the workplace, when accessing benefits, when looking for accommodation and in relation to the problems in Northern Ireland ${ }^{7}$. Sixty-five per cent of respondents stated clearly that they had seen or heard things directed against the Irish in Britain, which they had rejected, either openly or privately ${ }^{8}$. During the 1980 s, the Irish began to mobilise, members of the Irish community no longer wanted to remain "invisible". Their mobilisation was helped by the societal changes taking place in Britain where "difference" and "diversity" were becoming familiar terms. Britain was becoming a multicultural society and all sorts of groups were gaining recognition so why not the Irish? Irish voluntary organisations began to flourish with as their principle demand - recognition of the Irish as an ethnic group.

\section{Recognition of Irish diversity}

In this new British multicultural society immigrants were becoming "ethnic minorities". This term includes both the migrant generation and the second and

\footnotetext{
${ }^{4}$ Ibid, pp. 288-307.

${ }^{5}$ Nessa Winston, Between Two Places: A Case Study of Irish-born People Living in England, Dublin, The Irish National Committee of the European Cultural Foundation, 2000, p. 31.

${ }^{6}$ Ibid, p. 32.

${ }^{7}$ Mary Hickman et Bronwen Walter, Discrimination and the Irish Community in Britain, Londres, Commission for Racial Equality, 1997, p. 213.

${ }^{8}$ Idem.
} 
subsequent generations. An ethnic group has been defined as a community whose heritage offers important characteristics in common between its members and which makes them distinct from other communities ${ }^{9}$. According to Tariq Modood, ethnicity is a multi-faceted phenomenon based on physical appearance, subjective identification, cultural and religious affiliation, stereotyping and social exclusion ${ }^{10}$. In British society, having an "ethnic identity" became synonymous with having a different skin colour, with being "visible". How could the Irish then, who were not officially considered as immigrants in the first place and had remained invisible as such since the Second World War, hope to be recognised as an ethnic minority? Many decided to become "ethnically assertive", following the example of the lobbying of other minority groups.

Many minority groups began to exercise "ethnic assertiveness" during this period and the Irish were no different. This "ethnic assertiveness" arose from: "feelings of not being respected or of lacking access to public space, consisting of setting 'positive' images against traditional or dominant stereotypes"11. Members of the Irish community decided to organise themselves and were no longer willing to be excluded. They called for the Irish to be recognised in their own right as a distinct group with its own unique identity.

The Irish voluntary sector and members of the Irish community began to mobilise throughout England but particularly in London which became the epicentre of change at this time. They were principally effective at the local level and much lobbying was carried out in several London local authorities. Their main demand was recognition - recognition of the Irish experience in Britain, recognition of Irish cultural difference, recognition of an Irish ethnic identity. A number of local authorities, traditional enclaves for Irish immigration, reacted in favour of Irish demands, employing Irish Liaison Officers, organising conferences to discuss Irish issues, consulting with the local Irish community and recognising the Irish as having a distinct ethnic identity.

A citation from a report, published in Camden by the Irish present at one of these conferences, states that:

For us, the question of Irish ethnicity is a fait accompli. Our Irishness is our ethnicity. Our ethnicity is our Irishness. As a singular national group we share history, religions, traditions and experience, values and norms-social and political-that are unique and distinct; and in Britain and Camden we are minority. [...] By demanding of Camden to include "Irish" as a separate category in ethnic classification we want to be counted. It is estimated that approx $15 \%\left(1^{\text {st }}\right.$ and $2^{\text {nd }}$ generation) of the borough's population is Irish. Officially, in the Council's eyes,

\footnotetext{
${ }^{9}$ Tariq Modood et al., Ethnic Minorities in Britain: Diversity and Disadvantage, Londres, Policy Studies Institute, 1997, p. 13.

${ }^{10}$ Idem.

${ }^{11}$ Ibid, p. 290.
} 
we are invisible, but we are only invisible because they do not consider us to be a distinct group ${ }^{12}$.

In this citation, the Irish in Camden explain how they define their ethnicity. It is made up of many different elements but which are, according to them, unique and distinct. They want to be counted and to be included in ethnic classification systems for both the migrant generation but also for their second-generation children.

The Greater London Council (GLC) proved to be an important ally at this time. It was headed by Ken Livingstone, a Labour MP and a fervent advocate of the Irish in England. The GLC recognised the problems that the Irish community could encounter. It published a policy report on the Irish community in London in the early 1980s which was also the first official report recognising anti-Irish discrimination and racism ${ }^{13}$. At this time nearly $30 \%$ of the Irish population lived in this region ${ }^{14}$. This report was significant as the GLC acknowledged the importance of more funding for Irish community needs. It concluded that the Irish community was disadvantaged in many areas such as housing, employment and mental health. More importantly, it also recognised that the expression of Irish culture and identity should be promoted as it had been denigrated in the past in British society and called for recognition of the Irish as an ethnic minority. The report stated that:

The Irish should be recognised unequivocally as an ethnic minority with a unique and identifiable cultural heritage and should be included in all initiatives to improve the quality of life of London's ethnic minorities. [......] Historically, it was necessary to denigrate the Irish as treacherous, stupid and intractable in order to justify the British occupation of Ireland whilst at the same time covering over the massive exploitation of Ireland in economic terms ${ }^{15}$.

The report went on to speak about how the negative imaging concerning Ireland and Irishness undoubtedly did not encourage an open articulation of an Irish heritage or identity in English society:

It is evident in the way children of Irish parents feel that it is best to deny or refuse to acknowledge Irish origins because they know little of those origins, Irish History and Heritage, except what comes through the media.

It is evident in innumerable subtle ways in social life where Irish born prefer to keep a low profile especially during high points and crises in Anglo-Irish relations.

\footnotetext{
12 Camden Irish Conference Planning, The Voice of the Irish in Camden - Conference Report, Londres, Camden Irish Conference Planning Group, août 1990, p. 2.

${ }^{13}$ Greater London Council, Policy Report on the Irish Community - Ethnic Minorities in London, Londres, Greater London Council, 1983, p. 14.

${ }^{14}$ Liam Greenslade et al., Irish Migrants in Britain - Socio-economic and Demographic Conditions, Liverpool, The Institute of Irish Studies, 1991, p. 6.

${ }^{15}$ Greater London Council, op. cit., p. 11.
} 


\section{$[\ldots]$ It is evident in the PTA $^{16}$.}

The GLC was abolished in 1986, under the Thatcher government, before significant progress could be made but it greatly contributed to increasing the visibility of Irish issues and problems. Following its abolition, the onus was then on the local authorities to include an Irish dimension in ethnic monitoring procedures. However, because of the overwhelming association of ethnicity and "blackness" in Britain, the Irish were not automatically included in these procedures. The Irish voluntary sector continued its lobbying on local authorities, calling for them to recognise an Irish ethnic identity, but achieved limited success. According to the CRE report on the Irish community, only about half of the local authorities in London did some kind of monitoring of the Irish in the early $1990 \mathrm{~s}^{17}$.

At the time of the abolition of the GLC, the CRE itself did not monitor the Irish as a distinct ethnic group so official bodies, which used the ethnic categories recommended by this organism, did not include the Irish in their monitoring procedures. Due to the years of "invisibility" on an official level as an ethnic minority in Britain, the Irish were subsequently excluded from the "Ethnic Group" category when it was first introduced in the 1991 Census. This meant that the second-generation Irish who wished to express their Irish identity and heritage did not have the option to do so in this census.

Let us now turn our attention to this second-generation (those with one or two Irish-born parents) and look at what identity they perceive themselves as having. Do they see themselves as different from the English mainstream population? Do they recognise an Irish dimension to their identity or do they see themselves as simply English? It was during the 1980s that the first studies were carried out as to how these second-generation Irish children expressed their identity in England.

\section{The second generation - which identity?}

The first studies on second-generation Irish children that we are going to examine in this section were carried out in Catholic secondary schools in the 1980s and early 1990s. The majority of children of Irish descent are educated in these schools ${ }^{18}$. The analyses that follow relate therefore to the identities expressed by second-generation Irish Catholic children ${ }^{19}$.

In the early 1980s research was carried out in four Catholic secondary schools in London where 176 second-generation Irish children and thirty teachers,

\footnotetext{
${ }^{16}$ Ibid., p. 12.

${ }^{17}$ Mary Hickman et Bronwen Walter, op. cit., p. 64.

${ }^{18}$ Bronwen Walter, Sarah Morgan, Mary Hickman et Joseph Bradley, "Family Stories, Public Silence: Irish Identity Construction amongst the Second-generation Irish in England", Scot. Geog. J. 118(3), p. 202.

${ }^{19}$ To date no large-scale survey has been carried out on the ethnic identity of second-generation Irish Protestant children.
} 
who were mostly of Irish origin, were interviewed ${ }^{20}$. It was discovered that the children were aware of negative stereotyping of the Irish in Britain especially related to the situation in Northern Ireland. The problems or the "Troubles" in Northern Ireland were particularly serious at this time; the hunger strikes were taking place there. In addition, IRA bombings on mainland Britain, especially London, contributed significantly to experiences of prejudice and discrimination against the Irish in England.

These types of events undermined the confidence of the Irish and caused many people to play down their Irishness. It may not be surprising therefore that the teachers interviewed in this study preferred to ignore their students' Irish backgrounds and did not encourage them to discuss their Irish heritage at school. One teacher said that, "children and teachers would avoid any mention of the 'Troubles', to all intents and purposes, the children are English, they've assimilated into the British teenage culture" 21 .

Another teacher remarked that, "Once people come to England, they become English, to imply anything else makes it more difficult for them to integrate. They should merge with the host community"22. One teacher was afraid that if the differences were brought out the barriers would be heightened. This survey showed that for those second-generation children who wanted to openly express a cultural difference were not encouraged to do. This fear of heightening barriers, expressed by some of the teachers in the early 1980s, shows that they did not believe that the second-generation Irish children could both express Irishness as part of their identity and remain part of British society.

Other second-generation Irish children, 142 in total, were interviewed in Catholic schools in London and Birmingham in the mid-1980 $\mathrm{s}^{23}$. Approximately $56 \%$ of the children interviewed when asked to state their identity replied, "half English, half Irish", thus favouring a hybrid identity ${ }^{24}$.

It was discovered that ethnic prejudice was a significant issue for many of them and that they were well aware of anti-Irish prejudice. The research revealed that responses to this problem of prejudice were very closely linked to the different ethnic identities adopted by these people. Thirteen per cent adopted a "mainly English" identity and 8.5\% a "completely English" one ${ }^{25}$. The adoption of an English identity was a way of denying one's Irish origins in order to avoid the stigma attached to having Irish roots and the "Troubles" in Northern Ireland.

The children were asked how much pride they felt being of Irish descent. In most cases this source of pride was closely linked to their involvement in the Irish

\footnotetext{
${ }^{20}$ Joan Inglis, "The Irish in Britain - A Question of Identity", Irish Studies in Britain, no. 3, printemps/été 1982, pp.11-14.

${ }^{21}$ Ibid., p. 11.

${ }^{22}$ Idem.

23 Philip Ullah, "Second-generation Irish Youth: Identity and Ethnicity", New Community Journal of the Commission for Racial Equality, vol. XII, no. 2, été 1985, pp. 310-320.

${ }^{24}$ Ibid., p. 312.

${ }^{25}$ Idem.
} 
community and the many social and cultural activities that it generated. Their upbringing had led them to appreciate the close family atmosphere that could be found at such venues, and the sense of togetherness, which was so important for the development of a collective and positive sense of identity. The results of the interviews showed the relationship between the chosen identity and the degree of pride in one's Irish origins. It was found that they would feel Irish in situations in which this identity was salient and English in situations where that identity was most salient, thus, favouring a "situational identity" 26.

Mary Hickman looked more extensively at the role of Catholic schools in the formation of an Irish identity. She interviewed pupils in Catholic schools in London and Liverpool in the early 1990s. Eighty-one per cent of respondents claimed either "Irish" or "of Irish descent" in London whereas 65\% preferred a local or Liverpudlian identity in Liverpoo ${ }^{27}$. This survey showed a marked change in the articulation of Irishness. In London, there seems to have been a change in the early 1990s towards a more positive perception of Irishness and a willingness to embrace this identity.

However, she noted that the Catholic education system favoured a Catholic rather than an Irish identity and there was an absence of teaching about Ireland from the curriculum leaving cultural expression to the family and community. Those second-generation who struggled not to reject their Irishness were encouraged by their experience of Catholic schooling to maintain a low public profile for their identity.

These studies show that second-generation Irish children were aware of their Irish roots and heritage. Nevertheless, the negative stereotypes of the Irish and the "Troubles" in Northern Ireland did not encourage them to openly celebrate this part of their identity. Many of them went to Catholic schools where they were not encouraged to discuss their Irish background or Ireland in general. It was even felt by some teachers that they could not be both "Irish" and "British", nevertheless more than half the children in one study favoured a hybrid identity.

It is clear from these studies that the encouragement for these second-generation children to recognise and celebrate their Irishness came from the "inside" (family and community) and not from the "outside" (their education or English society). The inclusion of an Irish ethnic category in the 2001 Census was therefore the opportunity for recognition from the "outside". Irish community activists and the Irish voluntary sector had worked hard to gain this public recognition but results were disappointing.

\section{The 2001 Census}

When the "Ethnic Group" category was included for the first time in the 1991 Census, the argument used for its inclusion was that it would make statistical

\footnotetext{
${ }^{26}$ Robin Cohen, Frontiers of Identity: the British and the Others, New York, Longman Group ltd., 1994, p. 205.

${ }^{27}$ Mary Hickman, Religion, Class and Identity, Hants, Ashgate Publishing Company, 1995, p. 245.
} 
data available which would allow the Government to better meet the needs of ethnic minorities ${ }^{28}$. The Irish would have to wait for the publication of an official report by the CRE in 1997, which gave official recognition of Irish discrimination and disadvantage, and much lobbying from voluntary groups, especially the Federation of Irish Societies, before they were to be included in this category.

It was felt the Irish should be included under the "Ethnic Group" category for the following reasons: the situation of the Irish and other "visible" minorities was similar; benefits accorded to "visible" minorities were now needed by Irish people because of the similarity of their socio-economic position; the contribution of the Irish as migrant labour was not acknowledged and Irish cultural difference was not understood by the British. After more than ten years of lobbying by members of the Irish community and the Irish voluntary sector, the Office for National Statistics (ONS) finally included an Irish category under the "Ethnic Group" question in the 2001 Census

The CRE report had calculated the size of the Irish community in Britain at 2.5 million. This figure includes the migrant generation and the second-generation ${ }^{29}$. The number of people who ticked the "Ethnic Group" box was 641,804 or $1.21 \%$ of the British population ${ }^{30}$. When the figures are broken down 149,586 people who ticked the Irish "Ethnic Group" box were born in Britain $^{31}$. If we take this figure as the second-generation Irish, it is a long way off the figure calculated by the CRE at over one and a half million.

Possible reasons for this small figure were put forward in the initial findings of the Irish2 Project, which was the first large-scale project on second-generation Irish adults ${ }^{32}$. While the project organisers were interviewing second-generation Irish participants before the Census, it was discovered there was a lot of confusion surrounding the category on ethnicity and many had taken it to be a question on nationality. Most people had not read the explanatory text which said: "indicate your cultural background"33.

Furthermore, as we have seen from the studies on second-generation Irish children, many favoured a hybrid identity. This also applied to the second-generation adults interviewed for the Irish2 Project. Even though some second-generation Irish people described themselves as simply "Irish", over half favoured a mixed description of their identity, for example, "Anglo-Irish",

\footnotetext{
${ }^{28}$ Nada Afiouni, La gestion de la différence en France et en Grande-Bretagne: discours et pratiques, (thèse non-publiée), l’Université Aix-Marseille, décembre 2001, p. 99.

${ }^{29}$ Mary Hickman et Bronwen Walter, op. cit., p. 21.

${ }^{30} 2001$ Census, Key Statistics, (Table KS06- Ethnic Group).

312001 Census, Standard Tables, (Table S102- Sex and Country of Birth by Ethnic Group).

32 The Irish2 Project is the first large-scale research project about the children of Irish migrants to Britain. The project involved 12 discussion groups and 120 interviews with a wide range of people of Irish parentage, both professional and manual workers, people with one or two Irish-born parents from North and South, a balance of women and men with a broad age range in London, Glasgow, Manchester, Coventry and Banbury. Newsletters and the first findings of this project can be found at- http://www.apu.ac.uk/geography/progress/irish2/index.html.

${ }^{33}$ Bronwen Walter, “Making Sense of the Irish Census Question”, Irish Post, 22/1/06, p. 12.
} 
"London Irish", "English and Irish", "Irish-Italian" or "Irish-Pakistani",34. This would mean that the choice of "Irish" alone on the census form was too restrictive for those with hyphenated identities. The "visible" ethnic minorities had more choice in this category, and a "mixed" heading was included. Under this heading the following categories could be found: "white and black Caribbean"; "white and black African"; "white and Asian" and "other mixed".

However, it must not be forgotten that the Irish, either first or second-generation had not been accustomed to asserting their Irish identity on official documents in the past. It was also the first time people of Irish descent had been asked about their ethnicity in a national census. May of them did not realise what was being asked of them. The years of invisibility as an ethnic group in England may have gone some way in explaining the poor take-up of this category.

This low response rate for the question on ethnic identity by the Irish community has made official bodies doubt the usefulness of keeping this category in the future census of 2011. The ONS had been discussing possible exclusion of this category in late 2005 but lobbying by Irish voluntary organisations managed to avoid this for the moment. It was felt by Irish activists that the question on ethnicity in the 2001 Census was unclear and that the Census provided no guidance on what ethnicity was and to whom it applied and that the simple category "Irish" was too restrictive for those with mixed identities. For the 2011 Census, an expanded Irish category is being called for to allow for other mixed Irish backgrounds.

\section{Conclusion}

For much of the post World War II period, the Irish have been constructed as "invisible" in official discourse concerning ethnic minorities. They have been conspicuously absent from ethnic monitoring procedures and have been largely excluded from all official reports on ethnic minorities. In the 1980s, the research carried out on second-generation Irish children has shown that they have never been particularly encouraged to express their cultural difference or their Irish identity in English society. It may not be surprising then that these second-generation Irish children, now adults, were not aware that they were being asked to express their ethnicity in the 2001 census as they had not been accustomed to or encouraged to express their Irish identity in the public domain.

Research on the second-generation has shown that many are conscious of their Irish background but that a large majority favour a hybrid identity. The choice of simply "Irish" on the 2001 census form did not therefore suit the identities expressed by many of the second-generation. The low response rate of those of Irish decent to the ethnicity question in the 2001 Census should therefore be interpreted with caution. It should not be taken to mean that an Irish ethnic identity simply does not exist.

${ }^{34}$ Idem. 
Due to the low response rate, the inclusion of an "Irish" heading under the "Ethnic Group" question in the 2011 census remains uncertain. The Irish voluntary sector is now lobbying for the inclusion of a category that reflects more accurately the identities expressed by the Irish community. 